Issue no. $27 / 2018$

\title{
DOES TAX COMPETITION FOR CAPITAL DEFINE ENTREPRENEURSHIP TRENDS IN EASTERN EUROPE?
}

\begin{abstract}
Assoc. Prof. Dr. Yuriy Bilan
Faculty of Management and Economics, Tomas Bata University in Zlin, Czech Republic yuriy bilan@yahoo.co.uk

Prof. Dr. Serhiy Lyeonov Economic Cybernetic Department, Sumy State University, Ukraine s.lieonov@uabs.sumdu.edu.ua

Dr. Tetiana Vasylieva

Director of Oleg Balatskyi Academic and Research Institute of Finance, Economics and Management, Sumy State University, Ukraine tavasilyeva@fem.sumdu.edu.ua

\section{Senior Lecturer Dr. Yaryna Samusevych}

Accounting and Taxation Department, Sumy State University, Ukraine y.samusevych@uabs.sumdu.edu.ua
\end{abstract}

\section{DOI:10.24193/OJMNE.2018.27.02}

\begin{abstract}
The article deals with the analysis of relationships between tax competition and entrepreneurship development in Eastern European and Baltic countries during 2006-2017. Incomplete nature of tax systems reforming in these countries forms preconditions for their participation in cross-country tax competition in investment flows reallocation. The main instrument of the tax competition includes tax rates, which are defined by convergence tendencies in the studied countries. Other factors of the research are tax burden levels on the enterprise, tax administration indices and macroeconomic indicators. The entrepreneurship development at the country's level is characterized by a number of new businesses, the duration of their life cycle and their liquidation indices. The
\end{abstract}


Issue no. $27 / 2018$

calculations results show that higher levels of absolute tax rates for enterprises lead to the reduction of their creation volumes in the country's economy. High level of the tax burden partially restrains entrepreneurial activity. Tax administration plays a significant role in the provision of the country's tax competition. Time to pay taxes and the number of tax payments have a great impact on entrepreneurship development at different stages. The hypothesis is proved that tax factors impact on the entrepreneurial activity is reasonable to be observed within the context of the country's macroeconomic conditions.

Keywords: tax competition, entrepreneurship tendencies, tax rates, new businesses, tax administration.

\section{Introduction}

The economic globalization, innovative technologies development and lack of availability of resources cause the evolution of the economic competition theory from the level of the competition for production prime factors (land, labour, capital) to the stage where secondary sources of national economy income (tax revenues bases) are redistributed. It is shown in the development of tax competition phenomenon, mainly oriented to simplification of legislative terms to run business, and to a lesser extent, to the reduction of population taxation, in order to attract foreign sources of tax revenues. The world countries' governments continue to create various incentives to increase entrepreneurial activity to provide long-term economic growth (Khan, 2018). Either they focus on the human side of entrepreneurship, and create a suitable educational background (Lazányi, 2014; Bilan, 2014), or they concentrate on the hard facts, and utilize macroeconomic measures. One of the most flexible instruments of the state influence on the entrepreneurship consists in taxation terms (Lazányi, 2015). It is defined that tax factors do not only find investing processes development tendencies (Leonov, Vasylieva and Tsyganyuk, 2012) but also form general impact on the institutional regulation quality of the social sector (Vasilyeva et al. 2018).

The tax competition appears while reforming the tax system in order to attract taxpayers and investments to create additional working places and to stimulate economic growth (Field, 2003). On the other hand, Teather (2005) defines tax competition as the use of low effective tax rates by the country's government in order to involve investments and business activity to it. It is specific that tax competition appears when the tax system of one state formation influences the tax system of another one, usually through the impact on taxation (Goodspeed, 1998). 
Issue no. $27 / 2018$

The tax competition theory begins to actively develop in the second half of the twentieth century. Its beginning was an investigation of the regional tax competition, carried out by Tiebout (1956), who found its positive role since the offer of different services to regional governments leads to redistribution of households within the country due to their individual preferences.

Further development of this concept was made by Oates and Schwab (1998), who observed the problem regarding the reduction of the public services supply efficiency by the government through the attraction of investors via setting costs below the marginal level. The next stage was the development of the international tax competition theory. Studies of the foreign capital taxation carried out in the 60s of the twentieth century by Kemp (1961), MacDougall (1960), enabled to find out about state's tax system efficiency increase in case of non-resident capital taxation by the location of the investor as opposed to tax collection on the principle of the income source. In that period there were first attempts to define an optimal level of foreign capital income taxation. The regional tax competition theory, formalized by Zodrow and Mieszkowski (1986), based on Tiebout's basic model of the tax competition, enabled to demonstrate the capital mobility impact on tax rates level, which are set on the capital income, expressed by the inverse dependence.

In 1990s previous studies regarding international tax competition were systematized into one theory, which continued to develop in several directions: investigation of the public welfare level change, influenced by competitive factors, relationships between international tax competition and economic development rates, and national tax systems efficiency.

At the present time tax competition is an important factor to make investment decisions at the international level, which, taking into account production integration and mobility factors level increase, determines entrepreneurship activity at the countries' level given the difference of national and abroad taxation terms. Scientific researches confirm the significance of the tax aspects in the process of key performance indicators identification in the financial projection Balanced Scorecard (Hrytsenko and Vysochyna, 2012) and in the formation of the enterprise's value (Boyarko and Samusevych, 2011) which make necessary conditions for entrepreneurial activity efficiency. 
Issue no. $27 / 2018$

Nowadays tax factors are not only components which provide the financial efficiency of companies, but also define social entrepreneurial development tendencies (CriȘan, Dabija and Dinu, 2015) and innovative activity of business (Vasylieva and Kasyanenko, 2013). Given the development of the behavioural economy and business literacy growth at the modern stage, all entrepreneurial decisions are made with due account for a general list of benefits and risks in business starting (Prince, 2017) that cause necessity to study economic and tax factors impact on the entrepreneurial activity.

\section{Overview of existing models of tax competition for capital}

Study of the tax competition phenomenon leads to the formation of some models, which demonstrate its existence impact on the economy of jurisdictions-participants. While constructing the tax competition models, authors mostly observe two factors of production labour and capital, mobility level of which is considered by jurisdictions governments under conditions of tax competition. Table 1 demonstrates other assumptions and consequences, formed in different models of the tax competition.

Table 1. Tax competition models review

\begin{tabular}{|c|c|c|c|c|c|c|}
\hline Authors & \begin{tabular}{|c|} 
The object \\
of tax \\
competition
\end{tabular} & $\begin{array}{c}\text { Role of } \\
\text { government }\end{array}$ & $\begin{array}{c}\text { Changes in } \\
\text { jurisdiction } \\
\text { welfare }\end{array}$ & $\begin{array}{c}\text { Role of } \\
\text { jurisdiction } \\
\text { size }\end{array}$ & $\begin{array}{c}\text { Changes in } \\
\text { the tax } \\
\text { burden }\end{array}$ & $\begin{array}{c}\text { Instruments } \\
\text { of tax } \\
\text { competition }\end{array}$ \\
\hline $\begin{array}{l}\text { Hoyt } \\
(1991)\end{array}$ & capital & $\mathrm{N} / \mathrm{R}$ & $\begin{array}{l}\text { welfare } \\
\text { increase }\end{array}$ & $\begin{array}{c}\text { country size } \\
\text { raises its tax } \\
\text { competitiveness }\end{array}$ & $\begin{array}{c}\text { tax rates on } \\
\text { capital } \\
\text { decrease }\end{array}$ & $\begin{array}{l}\text { tax rates on } \\
\text { capital }\end{array}$ \\
\hline $\begin{array}{l}\text { Gordon and } \\
\text { Wilson } \\
(2002)\end{array}$ & $\begin{array}{l}\text { capital, } \\
\text { labour }\end{array}$ & $\begin{array}{l}\text { the decrease in } \\
\text { governments } \\
\text { waste raises } \\
\text { jurisdiction tax } \\
\text { competitiveness }\end{array}$ & $\begin{array}{l}\text { welfare } \\
\text { increase }\end{array}$ & $\mathrm{N} / \mathrm{R}$ & $\begin{array}{l}\text { tax rates } \\
\text { increase }\end{array}$ & $\begin{array}{c}\text { tax rates, } \\
\text { government } \\
\text { expenditures }\end{array}$ \\
\hline $\begin{array}{l}\text { Wilson } \\
(1999)\end{array}$ & $\begin{array}{l}\text { capital, } \\
\text { labour }\end{array}$ & $\mathrm{N} / \mathrm{R}$ & $\begin{array}{l}\text { welfare } \\
\text { decrease }\end{array}$ & $\mathrm{N} / \mathrm{R}$ & $\begin{array}{l}\text { tax rates } \\
\text { decrease }\end{array}$ & tax rates \\
\hline $\begin{array}{l}\text { Wildasin } \\
(1988)\end{array}$ & labour & $\begin{array}{l}\text { governments } \\
\text { subsidies raise }\end{array}$ & $\begin{array}{l}\text { welfare } \\
\text { increase }\end{array}$ & $\mathrm{N} / \mathrm{R}$ & $\mathrm{N} / \mathrm{R}$ & $\begin{array}{c}\text { tax rates and } \\
\text { government }\end{array}$ \\
\hline
\end{tabular}


Issue no. 27/2018

\begin{tabular}{|c|c|c|c|c|c|c|}
\hline & & $\begin{array}{l}\text { jurisdiction tax } \\
\text { competitiveness }\end{array}$ & & & & subsidies \\
\hline Enss (2008) & $\begin{array}{l}\text { capital, } \\
\text { labour }\end{array}$ & $\begin{array}{c}\text { establishment of } \\
\text { optimal regional } \\
\text { tax rates }\end{array}$ & $\begin{array}{c}\text { welfare } \\
\text { decrease }\end{array}$ & $\mathrm{N} / \mathrm{R}$ & $\begin{array}{l}\text { Shifting } \\
\text { of the tax } \\
\text { burden from } \\
\text { capital to } \\
\text { labour }\end{array}$ & tax rates \\
\hline $\begin{array}{l}\text { Kind, } \\
\text { Midelfart- } \\
\text { Knarvik } \\
\text { and } \\
\text { Schjelderup } \\
(2000)\end{array}$ & $\begin{array}{l}\text { capital, } \\
\text { labour }\end{array}$ & $\begin{array}{c}\text { governments } \\
\text { subsidies for } \\
\text { new tax objects } \\
\text { placing }\end{array}$ & $\mathrm{N} / \mathrm{R}$ & $\mathrm{N} / \mathrm{R}$ & $\begin{array}{l}\text { tax rates } \\
\text { increase/ } \\
\text { decrease for } \\
\text { different } \\
\text { countries }\end{array}$ & $\begin{array}{l}\text { tax rates and } \\
\text { government } \\
\text { subsidies }\end{array}$ \\
\hline $\begin{array}{l}\text { Haufler and } \\
\text { Wooton } \\
(2007)\end{array}$ & $\begin{array}{l}\text { capital, } \\
\text { labour }\end{array}$ & $\begin{array}{l}\text { governments } \\
\text { subsidies for } \\
\text { companies }\end{array}$ & $\begin{array}{c}\text { welfare } \\
\text { increase/ } \\
\text { decrease for } \\
\text { different } \\
\text { countries }\end{array}$ & $\begin{array}{c}\text { integration } \\
\text { effects for small } \\
\text { countries }\end{array}$ & $\begin{array}{l}\text { tax rates } \\
\text { decrease }\end{array}$ & $\begin{array}{c}\text { tax rates and } \\
\text { government } \\
\text { subsidies }\end{array}$ \\
\hline $\begin{array}{l}\text { Bucovetsky } \\
\text { (1991) }\end{array}$ & capital & $\mathrm{N} / \mathrm{R}$ & $\mathrm{N} / \mathrm{R}$ & \begin{tabular}{|c|} 
tax rates are \\
proportional to \\
the country size
\end{tabular} & $\begin{array}{c}\text { tax rates } \\
\text { differentiation }\end{array}$ & tax rates \\
\hline $\begin{array}{l}\text { Razin and } \\
\text { Sadka } \\
(1989)\end{array}$ & $\begin{array}{l}\text { capital, } \\
\text { labour }\end{array}$ & $\mathrm{N} / \mathrm{R}$ & $\mathrm{N} / \mathrm{R}$ & $\mathrm{N} / \mathrm{R}$ & $\begin{array}{c}\text { shifting of the } \\
\text { tax burden } \\
\text { from capital } \\
\text { to labour }\end{array}$ & $\begin{array}{l}\text { tax rates and } \\
\text { taxation } \\
\text { principles }\end{array}$ \\
\hline $\begin{array}{l}\text { Janeba } \\
(2001)\end{array}$ & capital & $\mathrm{N} / \mathrm{R}$ & $\mathrm{N} / \mathrm{R}$ & $\begin{array}{c}\text { country size and } \\
\text { development } \\
\text { raise its tax } \\
\text { competitiveness }\end{array}$ & $\begin{array}{c}\text { tax rates } \\
\text { decrease in } \\
\text { less } \\
\text { developed } \\
\text { countries }\end{array}$ & $\begin{array}{l}\text { tax regimes } \\
\text { and } \\
\text { subsidies }\end{array}$ \\
\hline $\begin{array}{l}\text { Fernandez } \\
(2016)\end{array}$ & labour & $\mathrm{N} / \mathrm{R}$ & $\begin{array}{l}\text { imbalances } \\
\text { in public } \\
\text { goods } \\
\text { provision }\end{array}$ & $\mathrm{N} / \mathrm{R}$ & $\begin{array}{l}\text { tax rates } \\
\text { decrease }\end{array}$ & $\begin{array}{l}\text { tax rates, } \\
\text { public goods }\end{array}$ \\
\hline $\begin{array}{l}\text { Bettendorf } \\
\text { and }\end{array}$ & capital, & $\mathrm{N} / \mathrm{R}$ & $\mathrm{N} / \mathrm{R}$ & $\begin{array}{c}\text { small countries } \\
\text { are more }\end{array}$ & tax rates & corporate tax \\
\hline
\end{tabular}


Issue no. $27 / 2018$

\begin{tabular}{|l|c|c|c|c|c|c|}
\hline $\begin{array}{l}\text { Vrijburg } \\
(2010)\end{array}$ & labour & & $\begin{array}{c}\text { sensitive to tax } \\
\text { policy of } \\
\text { competitors }\end{array}$ & decrease & rates \\
\hline $\begin{array}{l}\text { Huizinda } \\
\text { and Nielsen } \\
\text { (1997) }\end{array}$ & $\begin{array}{c}\text { capital, } \\
\text { labour }\end{array}$ & N/R & N/R & N/R & $\begin{array}{c}\text { Shifting } \\
\text { of the tax } \\
\text { burden from } \\
\text { capital to } \\
\text { labour }\end{array}$ & tax rates \\
\hline
\end{tabular}

Note: $\mathrm{N} / \mathrm{R}$ - not researched by authors

Source: own compilation

Hoyt's (1991) model focuses on the absolutely mobile capital. Assumptions of the model provide functioning of the limited number of countries in the global economy, the size of which enables to influence the international level of net profit on the capital. Every country sets tax rates, based on the assumption regarding tax rates stability in other countries.

Bucovetsky model (1991) takes into account the country's size and provides the fact that global economy is created by two types of the countries - small with an insufficient number of population and large, where population-level lets to influence the international norm of net profit on the capital. Other terms of countries' economies functioning are identical.

The tax competition model, proposed by Razin and Sadka (1989), provides functioning of two small countries, which influence the international return on capital. As a result of the tax competition, there is a symmetric balance, in which zero tax rate on reputation is acting. The capital taxation is performed according to resident principle, moreover, if there is no cooperation between countries, the tax burden will be laid from mobile factors of the capital on the immobile ones.

One should pay attention also to the Janeba's model (2001), which deals with states' competition for direct foreign investments location taking into account political stability factor, which has a great impact on investor's decision.

Results of the modified model's analysis enable to define positive and negative consequences of the tax competition impact on the economies functioning of countries- 
Issue no. $27 / 2018$

participants. On the other hand, the competitive nature of relationships leads to the improvement of welfare in small countries with a negative effect on big states. At the same time, the effect of tax competition investing has a critical point, in which its impact direction is changed. Positive impact on citizens' welfare after tax burden reduction happens when tax revenues enable the government to finance the production of public goods to satisfy inhabitants' needs since the further decrease of tax rates («race to the bottom» effect) causes lack of governments' financial resources to provide realization of its social and economic functions. However, the competitive character of relationships improves the welfare of small countries but has a negative effect on big states.

One can also point out that result depends on the level of tax competition terms stiffness. If there are not many participants and great volumes of the object, for which competition is held, tax competition will usually lead to the increase of fiscal policy efficiency, the establishment of optimal tax rates and an increase of public goods production quality, which together provide the welfare improvement. However, when tax competition terms are exaggerated, governments of jurisdiction decrease tax burden greatly. It leads to the lack of financing of the state's activity or tax burden is laid from some economic actors on others. Modern models of the tax competition confirm effects of profit shifting for multinational corporations when countries compete not for an actual location of the firm, but for the income declaration (Mukherjee, 2018).

Besides, one should mention that the result, which country's government desires to achieve, does not always depend only on the taxation terms, because other factors (economy development level, political stability etc.) influence the jurisdiction attraction for taxation base location on its territory. That is why, investigation of tendencies and consequences of tax competition have to consider not only the tax but also general economic aspects, and differences in sizes and level of countries' development.

\section{National tax systems development in the conditions of tax competition}

In the context of the study, it is reasonable to describe some types of taxes and charges from the viewpoint of their impact on tax competition objects moving between jurisdictions. The results of the research regarding taxes impact on taxpayers' mobility, 
carried out by Blöchliger and Pinero-Campos (2011), enable to define that taxes on capital and on corporations incomes - level of this taxes group influences the company's and returns to capital, stimulate shifting in jurisdiction, where profit is taxed to a lesser extent. Under conditions of the tax competition, this factor is observed as one of the reasons regarding the great decrease of the corporate tax standard rates on profit nation-wide, and to a lesser extent, the effective average tax rate over the last 20 years. At the same time, an extension of the tax base greatly compensates the tax rate reduction. In this context, one should mention, that corporate tax base mobility is different for various firms. Most business-activity depends on other factors at the local markets that is why such firms are not interested to be shifted between jurisdiction borders only from the viewpoint of tax considerations. Besides, many firms possess physical assets, which are hardly moved. It causes the fact that tax policy is developed setting higher tax rates in countries/regions, which characterized by a larger share of real estate companies, than in jurisdictions with high mobility of corporate tax bases.

Goods and service taxes group (consumption tax) is less significant, since there are local consumption taxes only in some countries, and harmonization of this taxes group in the international tax environment is very high. On the other hand, indirect taxes, set due to the origin principle (paid in jurisdiction, where goods are produced), define the result of tax competition to a greater extent, than consumption taxes, set due to the establishing principle (taxes are paid in jurisdiction, where goods are consumed), since firms are more mobile than consumers.

Taking into account the above, corporate income taxes, indirect taxes and social fees, paid directly by the employer, are chosen for the research. These types of taxes enable to evaluate the general level of direct and indirect tax burden on the company, which defines its investment decisions. In particular, on the example of Visegrad countries, scientists confirm the inverse relationship of corporate income tax rate тa FDI inflows (Bobenič Hintošová et al., 2018), which play a significant role for entrepreneurship increase in the country.

Analyzing features of the tax competition impact on the tax systems development, one can confirm the fact that its existence result is not only differentiation of taxation terms, but also tax systems convergence level increase caused by objective limitations regarding tax competitive benefits (necessity to provide sufficient tax revenues to realize social and 
Issue no. $27 / 2018$

economic functions of the state) and general vector of tax systems development in conditions of tax competitive relationships regarding tax burden decrease and taxation process simplification.

Nowadays there is a number of scientific studies, oriented to evaluate convergence processes in the international tax environment. In particular, one should point out investigations of the tax convergence in the European Union countries, carried out by Delgado (2013) during 1965-2010, which considers the calculation of the fiscal distance between indices of the country and average level for EU-15 by indicators of general tax burden and burden by the certain taxes groups. The results of calculations confirm the general convergence of tax burden in the European Union.

The $\sigma$-convergence use as an indicator of tax systems convergence is based on the variables dispersion indices, which describe the taxation system - a decrease of evaluated indicators dispersion level proves the existence of the convergent processes. The variation indices, Gini coefficient, Theil indices, regional asymmetry index, the Atkinson index are used while evaluating this parameter in the scientific literature. Therefore the optimal and most convenient index in use is coefficient of variation, because, firstly, it does not depend on the scale and dimension of variables, secondly, it is possible to interpret the obtained results either by absolute index or by its dynamics.

Base to carry out research of entrepreneurship tendencies under conditions of the tax competition are chosen Eastern European countries (Bulgaria, Czech Republic, Hungary, Moldova, Poland, Romania, Slovak Republic, Ukraine), and the Baltic countries (Estonia, Latvia, Lithuania). Tax systems of the mentioned countries are being constantly improved and are characterized by more dynamic rates of changes than tax systems of the developed EU Member States, which prove their efficiency in accordance with a general vector of these countries' economic policy. At the same time, the above countries are donors of the labour power for Western European countries owing to the high level of the domestic unemployment (Kleinschmidt, 2017), that also confirms the urgency to orient state regulation instruments to entrepreneurship development. That is why, one can provide great effects of the tax competition for the formed list of countries, taking into consideration the incompleteness of the capital redistribution processes at Europe's level, and insufficient 
Issue no. $27 / 2018$

coordination of the economic policy at the modern stage (Lyeonov, Vasylieva and Lyulyov, 2018). It confirms thesis regarding the establishment of the economies' regulation conception in the mentioned countries. Besides, previous calculations show that these countries are the main tax competitors among European countries (Boiko and Samusevych, 2017).

Thus, in order to characterize development tendencies of tax systems in the chosen countries in the context of their impact on entrepreneurship development, we will analyze statistic information regarding three types of taxes. Table 2 demonstrates the results of convergent processes evaluation and pairwise annual comparison of corporate tax rates variation.

Table 2. Descriptive statistics of corporate tax rates changes in Eastern European and Baltic countries

\begin{tabular}{|c|c|c|c|c|}
\hline \multicolumn{3}{|c|}{ Convergence } & \multicolumn{2}{|c|}{ Pairwise comparisons of means with equal variances } \\
\hline Year & mean & coefficient of variation & contrast & year \\
\hline 2003 & 21.773 & 0.383 & - & - \\
\hline 2004 & 18.864 & 0.393 & -2.909 & 2004 vs 2003 \\
\hline 2005 & 17.273 & 0.392 & 2.687 & 2005 vs 2003 \\
\hline 2006 & 17.000 & 0.380 & -4.500 & 2006 vs 2003 \\
\hline 2007 & 16.455 & 0.406 & -4.772 & 2007 vs 2003 \\
\hline 2008 & 16.091 & 0.394 & -5.318 & 2008 vs 2003 \\
\hline 2009 & 16.455 & 0.387 & -5.681 & 2009 vs 2003 \\
\hline 2010 & 16.182 & 0.389 & -5.318 & 2010 vs 2003 \\
\hline 2011 & 16.182 & 0.389 & -5.590 & 2011 vs 2003 \\
\hline 2012 & 15.818 & 0.371 & -5.590 & 2012 vs 2003 \\
\hline 2013 & 16.000 & 0.379 & -5.954 & 2013 vs 2003 \\
\hline 2014 & 15.818 & 0.374 & -5.772 & 2014 vs 2003 \\
\hline 2015 & 16.818 & 0.204 & -5.954 & 2015 vs 2003 \\
\hline
\end{tabular}


Issue no. $27 / 2018$

\begin{tabular}{|c|c|c|c|c|}
\hline 2016 & 16.818 & 0.204 & -4.954 & 2016 vs 2003 \\
\hline 2017 & 15.818 & 0.245 & -4.954 & 2017 vs 2003 \\
\hline 2018 & 16.273 & 0.249 & -5.954 & 2018 vs 2003 \\
\hline
\end{tabular}

Source: own calculations based on https://home.kpmg.com/xx/en/home/services/tax/tax-tools-andresources/tax-rates-online/corporate-tax-rates-table.html [Accessed 04/07/2018]

Let us point out that at the beginning of the analyzed period the coefficient of variation was higher than 0.33 , that shows the non-homogeneity of selection. However, in general, the corporate income tax rates are characterized by great convergence during the studied period and as of 2018 variation reach the level 0.249 that proves an essential convergence of tax systems. At the same time, maximum close rates of the corporate tax in the studied countries acted during 2015-2016. On the other hand, calculated average values on selection and their comparison result over years prove the fact that the gradual decrease of the corporate income tax rates is peculiar for the chosen countries. Such tendency may create essential motivation to increase the entrepreneurial activity in countries thanks to national and foreign investors.

Calculations regarding tendencies of indirect taxes change and their level in relation to different countries confirm the thesis about the maximum degree of the proper taxes harmonization (see Table 3). At the beginning of the research period, tax systems of the evaluated countries were characterized by a high degree of the convergence - the coefficient of variation is less than 0.33 . At the end of the research, the variation level was reduced greatly, and indirect income tax rates were more uniform as of 2009.

Table 3. Descriptive statistics of indirect tax rates changes in Eastern European and Baltic countries

\begin{tabular}{|c|c|c|c|c|}
\hline \multicolumn{2}{|c|}{ Convergence } & Pairwise comparisons of means with equal variances \\
\hline Year & mean & coefficient of variation & contrast & year \\
\hline 2005 & 19.800 & 0.105 & - & 2006 vs 2005 \\
\hline 2006 & 19.300 & 0.062 & -0.500 & \\
\hline
\end{tabular}


Issue no. $27 / 2018$

\begin{tabular}{|c|c|c|c|c|}
\hline 2007 & 19.300 & 0.062 & -0.500 & 2007 vs 2005 \\
\hline 2008 & 19.300 & 0.062 & -0.500 & 2008 vs 2005 \\
\hline 2009 & 19.700 & 0.056 & -0.100 & 2009 vs 2005 \\
\hline 2010 & 21.200 & 0.086 & 1.400 & 2010 vs 2005 \\
\hline 2011 & 21.500 & 0.084 & 1.700 & 2012 vs 2005 \\
\hline 2012 & 21.600 & 0.104 & 1.800 & 2013 vs 2005 \\
\hline 2013 & 21.700 & 0.101 & 1.900 & 2014 vs 2005 \\
\hline 2014 & 21.700 & 0.101 & 1.900 & 2015 vs 2005 \\
\hline 2015 & 21.700 & 0.101 & 1.900 & 2017 vs 2005 \\
\hline 2016 & 21.300 & 0.099 & 1.500 & 2018 vs 2005 \\
\hline 2017 & 21.200 & 0.103 & 1.400 & 1.400 \\
\hline 2018 & 21.200 & 0.103 & & \\
\hline
\end{tabular}

Source: own calculations based on https://home.kpmg.com/xx/en/home/services/tax/tax-tools-andresources/tax-rates-online/indirect-tax-rates-table.html [Accessed 04/07/2018]

The average level of this tax in terms of the period is between $19.3 \%$ and $21.7 \%$. Therefore, from 2005 till 2009 tax rate decrease is peculiar in general in the countries. Beginning from 2010 they are constantly growing. However, let us point out that the role of this tax to provide achievements of tax competition has secondary nature. Therefore, changes in the level of indirect taxation define reasonability to consider this type of the tax while modelling the entrepreneurship development.

Another type of taxes, which greatly influence the corporate tax burden level, includes social security taxes, paid by employers. Table 4 shows that, unlike other taxes, during the studied period, employer social security tax rates were characterized by divergent processes. In 2009 the coefficient of variation was 0.117 . In 2018 it grew three times. 
Issue no. $27 / 2018$

Table 4. Descriptive statistics of employer social security tax rates changes in Eastern European and Baltic countries

\begin{tabular}{|c|c|c|c|c|}
\hline \multicolumn{2}{|c|}{ Convergence } & Pairwise comparisons of means with equal variances \\
\hline Year & mean & coefficient of variation & contrast & year \\
\hline 2009 & 32.491 & 0.117 & - & - \\
\hline 2010 & 28.498 & 0.221 & -3.993 & 2010 vs 2009 \\
\hline 2011 & 27.820 & 0.229 & -4.671 & 2011 vs 2009 \\
\hline 2012 & 30.010 & 0.294 & -2.481 & 2013 vs 2009 \\
\hline 2013 & 30.390 & 0.280 & -2.101 & 2014 vs 2009 \\
\hline 2014 & 30.045 & 0.271 & -2.445 & 2015 vs 2009 \\
\hline 2015 & 29.551 & 0.283 & -2.940 & 2016 vs 2009 \\
\hline 2016 & 27.021 & 0.209 & -5.470 & 2017 vs 2009 \\
\hline 2017 & 26.699 & 0.209 & -5.792 & 2018 vs 2009 \\
\hline 2018 & 24.640 & 0.367 & -7.851 & \\
\hline
\end{tabular}

Source: own calculations based on https://home.kpmg.com/xx/en/home/services/tax/tax-tools-andresources/tax-rates-online/social-security-employer-tax-rates-table.html [Accessed 04/07/2018]

However, it is interesting to observe tendencies to changes of the general level of the given tax rates. During the investigated period its average level decreased from $32.491 \%$ to $24.640 \%$, therefore, reduction tendency was peculiar for the whole period of analysis. Thus, this tax at the formed selection of countries has great potential as an instrument of the tax competition.

Besides, variables of the research, which show the tax competition, include effective rates by separate taxes groups (see Table 5). Taxes for enterprise's profit, general sum of taxes on labour, and all other taxes, paid from business, have been separately selected for the research. Thus, these three indices demonstrate total tax burden on business considering all existed discounts in the country. On the other hand, one of the aspects regarding the country's tax system functioning, which defines its tax competitiveness, is also tax administration 
Issue no. $27 / 2018$

quality (Samusevych, 2014). So, a group of independent variables include also some indicators, which show the complexity of the tax administration in the country (Tax time, Tax payments).

Vasylieva at al. (2018b) confirm that the result of tax competition impact on the economic processes development in the country depends not only on taxation terms but also on peculiarities of social and economic development. That is why, control variables, which show the level of economic development (GDP growth, GDP per capita growth, GDP per capita), economic stability (Inflation) and formed a level of foreign investors' trust to the country (FDI) are selected for the research.

Table 5. Independent variables of research

\begin{tabular}{|l|l|l|}
\hline \multicolumn{1}{|c|}{$\begin{array}{c}\text { Variable } \\
\text { name }\end{array}$} & \multicolumn{1}{|c|}{ Variable description } & Source \\
\hline Corporate tax & $\begin{array}{l}\text { basic corporate tax rate (reduced rates are not } \\
\text { included) }\end{array}$ & KPMG (2018) \\
\hline Indirect tax & the standard rate of value added tax & KPMG (2018) \\
\hline Employer tax & highest employer social security rates & KPMG (2018) \\
\hline Profit tax & $\begin{array}{l}\text { amount of taxes on profits paid by the business - the } \\
\text { percentage of commercial profit }\end{array}$ & World Bank (2018) \\
\hline Labour tax & $\begin{array}{l}\text { amount of labour tax and contributions paid by the } \\
\text { business - the percentage of commercial profit }\end{array}$ & World Bank (2018) \\
\hline Other taxes & $\begin{array}{l}\text { other taxes payable by businesses (include the } \\
\text { amounts paid for property taxes, turnover taxes, and } \\
\text { other small taxes such as municipal fees and vehicle } \\
\text { and fuel taxes) - the percentage of commercial profit }\end{array}$ & World Bank (2018) \\
\hline Tax time & $\begin{array}{l}\text { time to prepare and pay taxes is the time, in hours per } \\
\text { year, it takes to prepare, file, and pay (or withhold) } \\
\text { three major types of taxes: the corporate income tax, } \\
\text { the value added or sales tax, and labour taxes, } \\
\text { including payroll taxes and social security } \\
\text { contributions. }\end{array}$ & World Bank (2018) \\
\hline
\end{tabular}


Issue no. $27 / 2018$

\begin{tabular}{|c|c|c|}
\hline Tax payments & $\begin{array}{l}\text { tax payments by businesses are the total number of } \\
\text { taxes paid by businesses, including electronic filing. } \\
\text { The tax is counted as paid once a year even if } \\
\text { payments are more frequent }\end{array}$ & World Bank (2018) \\
\hline Business cost & $\begin{array}{l}\text { the cost to start a business - the percentage of income } \\
\text { per capita }\end{array}$ & World Bank (2018) \\
\hline $\begin{array}{l}\text { Property } \\
\text { registration }\end{array}$ & procedures required to register property - number & World Bank (2018) \\
\hline Inflation & $\begin{array}{l}\text { inflation, as measured by the annual growth rate of the } \\
\text { GDP implicit deflator, shows the rate of price change } \\
\text { in the economy as a whole }\end{array}$ & World Bank (2018) \\
\hline GDP growth & $\begin{array}{l}\text { annual percentage growth rate of GDP at market } \\
\text { prices based on constant local currency. Aggregates } \\
\text { are based on constant } 2010 \text { U.S. dollars }\end{array}$ & World Bank (2018) \\
\hline $\begin{array}{l}\text { GDP per } \\
\text { capita growth }\end{array}$ & $\begin{array}{l}\text { annual percentage growth rate of GDP per capita } \\
\text { based on constant local currency. Aggregates are } \\
\text { based on constant } 2010 \text { U.S. dollars }\end{array}$ & World Bank (2018) \\
\hline $\begin{array}{l}\text { GDP per } \\
\text { capita }\end{array}$ & $\begin{array}{l}\text { gross domestic product divided by midyear population } \\
\text { in constant } 2010 \text { U.S. dollars. }\end{array}$ & World Bank (2018) \\
\hline FDI & $\begin{array}{l}\text { net inflows (new investment inflows less } \\
\text { disinvestment) in the reporting economy from foreign } \\
\text { investors, and is divided by GDP }\end{array}$ & World Bank (2018) \\
\hline
\end{tabular}

Kozubíková et al. (2015) confirm that SMEs enterprises define Market risk as the most important group of business risk in running the business. On the other hand, sufficient financial resources to run a business lead to its further activity efficiency (Belás et al., 2018). That is why, while evaluating tax factors to start a business by control variables, the model will also include indicators of complexity and of business creation value at the level of a certain country (Business cost, Property registration). 
Issue no. $27 / 2018$

\section{The relationship between tax competition and entrepreneurship trends}

The main indicators of entrepreneurship in the country include absolute indices of business creation, the average duration of its life cycle and business liquidation indices. Pomianek (2018) defines that at the modern stage of developing, small and medium-sized enterprises make the main business form, which is being started in the world. Table 6 demonstrates the main indicators of entrepreneurship, implemented in the research as dependent variables.

Table 6. Dependent variables of entrepreneurship

Variable name

New business

number of new limited liability corporations registered in the calendar year

New business number of new limited liability corporations registered in the density calendar year per 1,000 people ages 15-64

Enterprise birth rate

Business growth

Enterprise survival 3 rate

Enterprise survival 5 rate

Enterprise death rate

\section{Variable description}

Source

World Bank (2018)

World Bank (2018)

Eurostat

Eurostat

number of enterprises in the reference period ( $\mathrm{t}$ ) newly born in $\mathrm{t}-3$ Eurostat having survived to $t$ divided by the number of enterprise births in t- (2018) 3 - percentage

number of enterprises in the reference period $(t)$ newly born in $t-5$ Eurostat having survived to $t$ divided by the number of enterprise births in t- (2018) 5 - percentage

number of enterprise deaths in the reference period ( $\mathrm{t}$ ) divided by the number of enterprises active in $\mathrm{t}$ - percentage
Eurostat (2018)

Analyzing the generalized tendencies of entrepreneurship development in the Eastern European and Baltic countries (Table 7), one can point out the essential level of their variation between countries and in terms of periods, evidenced by standard deviation and min-max comparison. 
Issue no. $27 / 2018$

Table 7. Summarize statistics of entrepreneurship variables

\begin{tabular}{|l|c|c|c|c|c|}
\hline \multicolumn{1}{|c|}{ Variable name } & Obs & Mean & Std. Dev. & Min & Max \\
\hline New business & 119 & 25242.5 & 19950.59 & 4129 & 102745 \\
\hline New business density & 119 & 5.12646 & 4.382683 & 0.466435 & 20.76074 \\
\hline Enterprise birth rate & 80 & 13.19925 & 4.109485 & 3.81 & 24.88 \\
\hline Business growth & 71 & 2.932817 & 6.43885 & -13.64 & 35.47 \\
\hline Enterprise survival 3 rate & 80 & 54.47538 & 10.05047 & 23.23 & 90.55 \\
\hline Enterprise survival 5 rate & 71 & 40.80437 & 8.335042 & 17.91 & 70.13 \\
\hline Enterprise death rate & 79 & 11.47177 & 3.818447 & 5.77 & 29.05 \\
\hline
\end{tabular}

Results of new business creation tendencies calculation, influenced by tax factors, are presented in Table 8 .

Table 8. Regression analysis of tax competition influence on new business in Eastern European and Baltic countries

\begin{tabular}{|l|c|l|l|l|l|r|}
\hline Variables & Model 1 & Model 2 & Model 3 & Model 4 & Model 5 & Model 6 \\
\hline $\begin{array}{l}\text { Corporate } \\
\text { tax }\end{array}$ & $-848.26^{*}$ & 29.78 & & 556.26 & 442.22 & -205.20 \\
& $(-1.68)$ & $(0.05)$ & & $(0.66)$ & $(0.53)$ & $(-0.60)$ \\
\hline Indirect tax & - & $-2046.73^{* * *}$ & & $2127.02 * *$ & $2275.50 * * *$ & \\
& $1137.65^{* *}$ & $(-3.37)$ & & $(2.66)$ & $(2.84)$ & \\
\hline $\begin{array}{l}\text { Employer } \\
\text { tax }\end{array}$ & & $-431.84^{* *}$ & & -328.17 & -128.03 & \\
\hline Profit tax & $(-2.40)$ & & $(-1.00)$ & $(-0.43)$ & \\
& & & 320.98 & & & \\
\hline Labour tax & & & $(0.72)$ & & & \\
\hline
\end{tabular}


On-line Journal Modelling the New Europe

Issue no. $27 / 2018$

\begin{tabular}{|c|c|c|c|c|c|c|}
\hline & & & $(0.62)$ & & & \\
\hline Other taxes & & & $\begin{array}{l}-2.39 \\
(-0.48)\end{array}$ & $\begin{array}{l}-15.87 \\
(-0.70)\end{array}$ & $\begin{array}{l}-18.82 \\
(-0.83)\end{array}$ & \\
\hline Tax time & & & $\begin{array}{l}69.98^{*} \\
(1.75)\end{array}$ & $\begin{array}{c}238.27 * * * \\
(3.38)\end{array}$ & $\begin{array}{c}221.88^{* * * *} \\
(3.16)\end{array}$ & \\
\hline $\begin{array}{l}\text { Tax } \\
\text { payments }\end{array}$ & & $\begin{array}{c}-2652.99 * * * \\
(-4.02)\end{array}$ & $\begin{array}{c}-1160.31 * * * \\
(-2.83)\end{array}$ & $\begin{array}{c}-576.09 \\
(-1.00)\end{array}$ & $\begin{array}{l}-559.26 \\
(-0.97)\end{array}$ & $\begin{array}{c}-1040.39 * * * \\
(-3.05)\end{array}$ \\
\hline $\begin{array}{l}\text { Business } \\
\text { cost }\end{array}$ & & & & $\begin{array}{c}5870.96 * * * \\
(4.22)\end{array}$ & $\begin{array}{c}6565.99 * * * \\
(5.00)\end{array}$ & $\begin{array}{c}-429.16 \\
(-0.37)\end{array}$ \\
\hline Inflation & $\begin{array}{l}226.52 \\
(1.21)\end{array}$ & $\begin{array}{l}213.22 \\
(1.35)\end{array}$ & $\begin{array}{c}381.69 * * \\
(1.99)\end{array}$ & $\begin{array}{l}446.09 \\
(1.43)\end{array}$ & & $\begin{array}{c}426.23 * * \\
(2.63)\end{array}$ \\
\hline $\begin{array}{l}\text { GDP } \\
\text { growth }\end{array}$ & $\begin{array}{c}294.35 * \\
(1.77)\end{array}$ & & & & & \\
\hline $\begin{array}{ll}\text { GDP } & \text { per } \\
\text { capita } & \\
\text { growth } & \end{array}$ & & $\begin{array}{c}320.22 * * \\
(2.08)\end{array}$ & $\begin{array}{l}277.41 \\
(1.49)\end{array}$ & $\begin{array}{l}86.59 \\
(0.26)\end{array}$ & $\begin{array}{l}116.52 \\
(0.34)\end{array}$ & $\begin{array}{c}312.43 * * \\
(2.08)\end{array}$ \\
\hline FDI & $\begin{array}{c}-190.11^{* *} \\
(1.21)\end{array}$ & $\begin{array}{c}-194.20^{* *} \\
(-2.31)\end{array}$ & $\begin{array}{l}-25.43 \\
(-0.22)\end{array}$ & $\begin{array}{l}-201.64 \\
(-1.00)\end{array}$ & $\begin{array}{l}-199.55 \\
(-0.98)\end{array}$ & $\begin{array}{l}-20.37 \\
(-0.54)\end{array}$ \\
\hline _cons & $\begin{array}{c}65569.69 * \\
(4.10)\end{array}$ & $\begin{array}{c}94636.66 * * * \\
(5.26)\end{array}$ & $\begin{array}{c}24583.27 * * * \\
(4.89)\end{array}$ & $\begin{array}{c}-44894.12 * * \\
(-1.97)\end{array}$ & $\begin{array}{c}- \\
53278.08 * * \\
(-2.40)\end{array}$ & $\begin{array}{c}34058.51 * * * \\
(3.70)\end{array}$ \\
\hline $\begin{array}{l}\text { Number of } \\
\text { observations }\end{array}$ & 108 & 75 & 119 & 75 & 75 & 119 \\
\hline $\mathrm{F}$ & 16.93 & 42.74 & 17.57 & 88.97 & 85.56 & 23.07 \\
\hline Prob $>F$ & 0.0046 & 0.0000 & 0.0247 & 0.0000 & 0.0000 & 0.0008 \\
\hline
\end{tabular}

regression 
Issue no. $27 / 2018$

Let us point out that the combination of various factorial features in models leads to differentiation of the obtained results of qualitative impact. Based on the statistically valuable dependences, one can mention that corporate tax rate increase on the average by $1 \%$ decreases the number of new businesses by 848.26 units, respectively the growth of employer tax reduces the number of companies by 431.84 . At the same time, the indirect tax impact is ambiguous, comparing different models. Therefore effective tax rates are not characterized by statistically relevant results, which is quite predictable, considering the fact that owners focus on formal taxation terms while creating the enterprise.

The effect of certain tax administration indicators is rather interesting. Despite the assumptions that tax administration complexity destimulates business development, tax time indicator has a stable positive relation with the resulting variable, confirmed by different models. On the other hand, the increase of tax payments number, paid by business, leads to the essential reduction of entrepreneurial initiatives.

Among control variables, one can point out the expected positive impact of such parameters as GDP growth and GDP per capita growth on business creation, which proves the important role of economic development level to provide the entrepreneurial activity. One should take into account the positive relation of inflation and new businesses creation, which demonstrates the positive impact of creeping inflation on economic development.

The business cost has a positive impact on business creation, that however, can be the result of different countries' economies comparative characterization - the analogical procedures cost in more developed countries exceeds indices of the less developed countries.

FDI growth also limits the creation of new businesses, caused by growing competition of the companies thanks to the foreign capital inflow, which leads to the increase of the income market barriers.

One should take into account the results, obtained for a relative index of new business creation - new business density (Table 9).

According to the table data we can point out that among indicators of the tax burden, there is a statistically relevant impact for indirect tax and other taxes. Therefore, the indirect tax rates increase reduces new businesses indices, whereas other taxes are their stimulators according to the results of calculations. 
Issue no. $27 / 2018$

There is a small positive impact for tax payments among tax administration parameters, and there is also the limiting effect of the tax time. One should mention the great limiting role of complexity indices and business creation cost regarding new business density, confirmed by calculations.

Table 9. Regression analysis of tax competition influence on new business density in Eastern European and Baltic countries

\begin{tabular}{|c|c|c|c|c|c|c|c|}
\hline Variables & Model 1 & Model 2 & Model 3 & Model 4 & Model 5 & Model 6 & Model 7 \\
\hline Corporate tax & $\begin{array}{c}-0.07 \\
(-0.41)\end{array}$ & $\begin{array}{l}-0.23 \\
(-1.28)\end{array}$ & $\begin{array}{c}-0.10 \\
(-0.59)\end{array}$ & & & & \\
\hline Indirect tax & $\begin{array}{l}-0.36^{* *} \\
(-2.16)\end{array}$ & $\begin{array}{l}-0.53 * * \\
(-2.56)\end{array}$ & $\begin{array}{l}-0.42 * * \\
(-2.60)\end{array}$ & & & & \\
\hline Employer tax & $\begin{array}{c}0.01 \\
(0.22)\end{array}$ & $\begin{array}{l}-0.01 \\
(-0.22)\end{array}$ & $\begin{array}{c}0.03 \\
(0.58)\end{array}$ & & & & \\
\hline Profit tax & & & & & $\begin{array}{l}-0.03 \\
(-0.34)\end{array}$ & $\begin{array}{l}-0.02 \\
(-0.27)\end{array}$ & $\begin{array}{c}-0.03 \\
(-0.30)\end{array}$ \\
\hline Labor tax & & & & & & $\begin{array}{c}0.05 \\
(0.56)\end{array}$ & $\begin{array}{l}-0.10 \\
(-1.45)\end{array}$ \\
\hline Other taxes & & & & & $\begin{array}{l}0.15^{* *} \\
(2.17)\end{array}$ & $\begin{array}{l}0.14 * * \\
(2.03)\end{array}$ & $\begin{array}{c}0.42 * * * \\
(3.68)\end{array}$ \\
\hline Tax time & & $\begin{array}{c}-0.01 * * * \\
(-3.16)\end{array}$ & $\begin{array}{l}-0.01 \\
(-0.87)\end{array}$ & $\begin{array}{l}-0.00 \\
(-0.14)\end{array}$ & & & $\begin{array}{l}0.00 \\
(0.33)\end{array}$ \\
\hline $\begin{array}{l}\text { Tax } \\
\text { payments }\end{array}$ & & $\begin{array}{l}-0.00 \\
(-0.11)\end{array}$ & $\begin{array}{c}0.00 \\
(0.29)\end{array}$ & $\begin{array}{l}0.01 * \\
(1.92)\end{array}$ & & & $\begin{array}{l}0.00 \\
(0.34)\end{array}$ \\
\hline Business cost & $\begin{array}{l}-0.28^{*} \\
(-1.76)\end{array}$ & & $\begin{array}{l}-0.16 \\
(-0.79)\end{array}$ & $\begin{array}{l}-0.19 * * \\
(-2.60)\end{array}$ & $\begin{array}{l}-0.16^{* *} \\
(-2.54)\end{array}$ & $\begin{array}{c}-0.17^{* *} \\
(-2.48)\end{array}$ & $\begin{array}{c}-0.37 * * * \\
(-4.50)\end{array}$ \\
\hline
\end{tabular}


Issue no. $27 / 2018$

\begin{tabular}{|c|c|c|c|c|c|c|c|}
\hline $\begin{array}{l}\text { Property } \\
\text { registration }\end{array}$ & $\begin{array}{c}-0.37 \\
(-1.14)\end{array}$ & & $\begin{array}{l}-0.04 \\
(-0.09)\end{array}$ & $\begin{array}{l}-0.61 * * \\
(-2.63)\end{array}$ & $\begin{array}{l}-0.39 * \\
(-1.80)\end{array}$ & $\begin{array}{l}-0.37 * \\
(-1.68)\end{array}$ & $\begin{array}{l}-0.47^{*} \\
(-1.81)\end{array}$ \\
\hline Inflation & & $\begin{array}{c}0.01 \\
(0.20)\end{array}$ & & & & & $\begin{array}{c}0.00 \\
(0.07)\end{array}$ \\
\hline GDP growth & $\begin{array}{c}0.19 * * * \\
(4.42)\end{array}$ & $\begin{array}{c}0.19 * * * \\
(3.08)\end{array}$ & $\begin{array}{c}0.20 * * * \\
(4.88)\end{array}$ & $\begin{array}{c}0.10 * * * \\
(3.48)\end{array}$ & $\begin{array}{c}0.10 * * * \\
(3.38)\end{array}$ & & \\
\hline $\begin{array}{l}\text { GDP per } \\
\text { capita growth }\end{array}$ & & & & & & $\begin{array}{c}0.09^{* * *} \\
(3.38)\end{array}$ & $\begin{array}{l}0.09^{*} \\
(1.76)\end{array}$ \\
\hline FDI & $\begin{array}{c}-0.04 \\
(-1.55)\end{array}$ & $\begin{array}{l}-0.02 \\
(-0.57)\end{array}$ & & & & & \\
\hline _cons & $\begin{array}{c}17.33 * * * \\
(3.74)\end{array}$ & $\begin{array}{c}25.08 * * * \\
(4.57)\end{array}$ & $\begin{array}{c}17.49 * * * \\
(3.62)\end{array}$ & $\begin{array}{c}8.79 * * * \\
(5.94)\end{array}$ & $\begin{array}{c}7.79 * * * \\
(5.40\end{array}$ & $\begin{array}{l}6.03 * \\
(1.87)\end{array}$ & $\begin{array}{c}11.92 * * * \\
(4.06)\end{array}$ \\
\hline $\begin{array}{l}\text { Number of } \\
\text { observations }\end{array}$ & 75 & 75 & 75 & 119 & 119 & 119 & 119 \\
\hline $\mathrm{F}$ & 32.06 & 26.77 & 31.81 & 24.21 & 25.76 & 25.22 & 53.95 \\
\hline Prob $>F$ & 0.0000 & 0.0008 & 0.0001 & 0.0002 & 0.0001 & 0.0003 & 0.0000 \\
\hline
\end{tabular}

regression

Let us point out that the relative level of new businesses creation greatly depends on the level of corporate tax and employer tax rates, for which statistically relevant inverse effect is confirmed (see Table 10). On the other hand, different groups of effective tax rates are also characterized by the statistically relevant impact on the enterprise birth rate, and their growth essentially reduces the resulting variable index. Restraining impact on the company's creation in certain constructed models is obtained for the tax administration indices. 
Issue no. $27 / 2018$

Table 10. Regression analysis of tax competition influence on enterprise birth rate in Eastern

European and Baltic countries

\begin{tabular}{|c|c|c|c|c|c|c|c|}
\hline Variables & Model 1 & Model 2 & Model 3 & Model 4 & Model 5 & Model 6 & Model 7 \\
\hline Corporate tax & $\begin{array}{l}-0.48^{*} \\
(-1.92)\end{array}$ & $\begin{array}{l}-0.56 * * \\
(-2.24)\end{array}$ & $\begin{array}{c}-0.96 * * * \\
(-3.14)\end{array}$ & $\begin{array}{l}-0.91 * * \\
(-3.06)\end{array}$ & $\begin{array}{c}-1.02 * * * \\
(-4.28)\end{array}$ & & $\begin{array}{c}-0.86^{* * *} \\
(-3.96)\end{array}$ \\
\hline Indirect tax & & $\begin{array}{l}0.18 \\
(0.75)\end{array}$ & $\begin{array}{l}-0.00 \\
(-0.00)\end{array}$ & $\begin{array}{l}-0.06 \\
(-0.24)\end{array}$ & $\begin{array}{l}-0.26 \\
(-1.37)\end{array}$ & & $\begin{array}{l}-0.22 \\
(-1.05)\end{array}$ \\
\hline Employer tax & & $\begin{array}{l}0.12 \\
(0.74)\end{array}$ & $\begin{array}{l}0.02 \\
(0.11)\end{array}$ & $\begin{array}{c}0.10 \\
(0.77)\end{array}$ & $\begin{array}{c}-0.44 * * * \\
(-3.09)\end{array}$ & & $\begin{array}{c}-0.34 * * * \\
(-2.61)\end{array}$ \\
\hline Profit tax & & & & & & $\begin{array}{l}-0.53 * * \\
(-2.56)\end{array}$ & \\
\hline Labour tax & & & & & & $\begin{array}{c}-0.58 * * * \\
(-5.20)\end{array}$ & \\
\hline Other taxes & & & & & & $\begin{array}{l}-0.26^{*} \\
(-1.67)\end{array}$ & \\
\hline Tax time & & & $\begin{array}{c}-0.01 \\
(-0.52)\end{array}$ & $\begin{array}{c}-0.02 * * * \\
(-3.18)\end{array}$ & $\begin{array}{l}-0.00 \\
(-0.85)\end{array}$ & & \\
\hline Tax payments & & & $\begin{array}{c}-0.02 * * * \\
(-3.19)\end{array}$ & $\begin{array}{c}-0.03 \\
(-1.24)\end{array}$ & $\begin{array}{l}0.04 * \\
(1.83)\end{array}$ & & \\
\hline Business cost & $\begin{array}{l}-0.07 \\
(-0.33)\end{array}$ & $\begin{array}{l}0.23 \\
(0.91)\end{array}$ & $\begin{array}{c}0.05 \\
(0.23)\end{array}$ & $\begin{array}{l}0.12 \\
(0.61)\end{array}$ & $\begin{array}{c}0.09 \\
(0.60)\end{array}$ & $\begin{array}{l}-0.02 \\
(-0.11)\end{array}$ & $\begin{array}{c}0.07 \\
(0.45)\end{array}$ \\
\hline $\begin{array}{l}\text { Property } \\
\text { registration }\end{array}$ & & & & & $\begin{array}{c}-3.17 * * * \\
(-5.73)\end{array}$ & $\begin{array}{c}-2.50 * * * \\
(-5.82)\end{array}$ & $\begin{array}{c}-3.09 * * * \\
(6.05)\end{array}$ \\
\hline Inflation & $\begin{array}{l}0.16^{*} \\
(1.83)\end{array}$ & $\begin{array}{l}-0.07 \\
(0.28)\end{array}$ & $\begin{array}{c}-0.21 \\
(-0.96)\end{array}$ & $\begin{array}{l}-0.22 \\
(-1.06)\end{array}$ & $\begin{array}{l}-0.24 \\
(-1.43)\end{array}$ & $\begin{array}{l}0.32 * * \\
(2.49)\end{array}$ & $\begin{array}{l}-0.19 \\
(-1.12)\end{array}$ \\
\hline
\end{tabular}


Issue no. $27 / 2018$

\begin{tabular}{|c|c|c|c|c|c|c|c|}
\hline GDP growth & & $\begin{array}{l}0.14^{*} \\
(1.78)\end{array}$ & & & & $\begin{array}{c}0.01 \\
(0.16)\end{array}$ & \\
\hline $\begin{array}{l}\text { GDP per } \\
\text { capita }\end{array}$ & $\begin{array}{c}-0.00 \\
(-0.30)\end{array}$ & & $\begin{array}{c}0.00 \\
(0.74)\end{array}$ & & & & $\begin{array}{l}-0.00 \\
(-1.06)\end{array}$ \\
\hline FDI & & $\begin{array}{c}0.00 \\
(0.28)\end{array}$ & $\begin{array}{l}-0.04 \\
(-0.57)\end{array}$ & $\begin{array}{l}-0.03 \\
(-0.50)\end{array}$ & & $\begin{array}{c}-0.04 \\
(-0.81)\end{array}$ & $\begin{array}{c}-0.04 \\
(-1.12)\end{array}$ \\
\hline _cons & $\begin{array}{c}22.45 * * * \\
(4.68)\end{array}$ & $\begin{array}{l}14.37^{*} \\
(1.75)\end{array}$ & $\begin{array}{c}31.88 * * * \\
(4.32)\end{array}$ & $\begin{array}{c}32.59 * * * \\
(4.47)\end{array}$ & $\begin{array}{c}64.26 * * * \\
(8.10)\end{array}$ & $\begin{array}{c}48.84 * * * \\
(9.05)\end{array}$ & $\begin{array}{c}59.52 * * * \\
(7.41)\end{array}$ \\
\hline $\begin{array}{l}\text { Number of } \\
\text { observations }\end{array}$ & 80 & 69 & 69 & 69 & 69 & 80 & 69 \\
\hline$F$ & 9.96 & 14.18 & 26.65 & 26.30 & 73.02 & 64.36 & 66.73 \\
\hline Prob $>F$ & 0.0412 & 0.0480 & 0.0016 & 0.0009 & 0.0000 & 0.0000 & 0.0000 \\
\hline
\end{tabular}

regression

The business cost has no statistically relevant impact on the enterprise birth rate, but a number of property registration procedures decreases the resulting index of the enterprise's creation.

Despite the relevant results, obtained in general for indices of enterprises creation, let us point out that for the index business growth there is no stable effect of its dependence on the relative taxation levels (Table 11).

Table 11. Regression analysis of tax competition influence on business growth in Eastern European and Baltic countries

\begin{tabular}{|l|c|c|c|c|l|l|c|}
\hline Variables & Model 1 & Model 2 & Model 3 & Model 4 & Model 5 & Model 6 & Model 7 \\
\hline Corporate tax & & -0.95 & & & & & -1.35 \\
& & $(-1.12)$ & & & & & $(-1.64)$ \\
\hline
\end{tabular}


Issue no. $27 / 2018$

\begin{tabular}{|c|c|c|c|c|c|c|c|}
\hline Indirect tax & & $\begin{array}{c}0.36 \\
(0.46)\end{array}$ & & & & & $\begin{array}{c}0.97 \\
(1.35)\end{array}$ \\
\hline Employer tax & $\begin{array}{c}0.31 \\
(0.58)\end{array}$ & $\begin{array}{l}-0.26 \\
(-0.40)\end{array}$ & & & & & $\begin{array}{c}-0.33 \\
(-0.52)\end{array}$ \\
\hline Profit tax & & & $\begin{array}{c}0.97 \\
(1.06)\end{array}$ & $\begin{array}{c}0.98 \\
(1.06)\end{array}$ & & & \\
\hline Other taxes & & & & $\begin{array}{l}0.07 \\
(0.19)\end{array}$ & $\begin{array}{c}0.04 \\
(0.11)\end{array}$ & & \\
\hline Tax time & $\begin{array}{l}0.04^{*} \\
(1.98)\end{array}$ & $\begin{array}{c}0.03 \\
(1.62)\end{array}$ & $\begin{array}{l}0.06^{* *} \\
(1.24)\end{array}$ & $\begin{array}{l}0.06^{* *} \\
(2.73)\end{array}$ & $\begin{array}{l}0.06^{* *} \\
(2.63)\end{array}$ & $\begin{array}{l}0.06^{* *} \\
(2.66)\end{array}$ & $\begin{array}{c}0.03 \\
(1.15)\end{array}$ \\
\hline Tax payments & & $\begin{array}{l}-0.10 * \\
(1.73)\end{array}$ & $\begin{array}{c}0.06 \\
(1.24)\end{array}$ & $\begin{array}{c}0.06 \\
(1.24)\end{array}$ & $\begin{array}{c}0.06 \\
(1.12)\end{array}$ & $\begin{array}{c}0.06 \\
(1.12)\end{array}$ & $\begin{array}{c}0.09 \\
(1.46)\end{array}$ \\
\hline Business cost & $\begin{array}{c}-0.54 \\
(-0.54)\end{array}$ & $\begin{array}{l}-0.68 \\
(-0.67)\end{array}$ & $\begin{array}{c}-0.69 \\
(-0.62)\end{array}$ & $\begin{array}{c}-0.68 \\
(-0.60)\end{array}$ & $\begin{array}{l}-0.45 \\
(-0.41)\end{array}$ & $\begin{array}{c}-0.46 \\
(-0.42)\end{array}$ & \\
\hline $\begin{array}{l}\text { Property } \\
\text { registration }\end{array}$ & & & & & & & $\begin{array}{c}1.58 \\
(0.42)\end{array}$ \\
\hline Inflation & $\begin{array}{l}-0.07 \\
(-0.16)\end{array}$ & $\begin{array}{l}-0.21 \\
(-0.45)\end{array}$ & $\begin{array}{l}0.70 * \\
(1.85)\end{array}$ & $\begin{array}{l}0.69^{*} \\
(1.77)\end{array}$ & $\begin{array}{c}0.63 \\
(1.64)\end{array}$ & $\begin{array}{l}0.64 * \\
(1.71)\end{array}$ & $\begin{array}{c}0.42 \\
(1.03)\end{array}$ \\
\hline GDP growth & $\begin{array}{l}0.61 * * \\
(2.71)\end{array}$ & $\begin{array}{l}0.57 * * \\
(2.27)\end{array}$ & & & & & \\
\hline GDP per capita & & & $\begin{array}{l}0.00^{* *} \\
(2.14)\end{array}$ & $\begin{array}{l}0.00^{* *} \\
(2.13)\end{array}$ & $\begin{array}{l}0.00^{* *} \\
(2.00)\end{array}$ & $\begin{array}{l}0.00^{* *} \\
(2.02)\end{array}$ & $\begin{array}{l}0.00 * \\
(1.96)\end{array}$ \\
\hline _cons & $\begin{array}{l}-15.06 \\
(-0.94)\end{array}$ & $\begin{array}{l}10.87 \\
(0.35)\end{array}$ & $\begin{array}{c}-47.99 * * \\
(-2.45)\end{array}$ & $\begin{array}{c}-48.55 * * \\
(-2.43)\end{array}$ & $\begin{array}{c}-37.71 * * \\
(-2.20)\end{array}$ & $\begin{array}{c}-37.49 * * \\
(-2.22)\end{array}$ & $\begin{array}{l}-25.17 \\
(-0.72)\end{array}$ \\
\hline Number of & 69 & 69 & 71 & 71 & 71 & 71 & 69 \\
\hline
\end{tabular}


Issue no. $27 / 2018$

\begin{tabular}{|l|c|c|c|c|c|c|c|}
\hline observations & & & & & & & \\
\hline $\mathrm{F}$ & 2.82 & 2.49 & 2.88 & 2.43 & 2.64 & 3.22 & 2.15 \\
\hline Prob $>\mathrm{F}$ & 0.0246 & 0.0228 & 0.0163 & 0.0306 & 0.0252 & 0.0125 & 0.0474 \\
\hline
\end{tabular}
regression

On the other hand, tax administration indices are characterized by the statistically relevant effect of impact on business growth. The stimulating impact is obtained for tax time, whereas the restraining effect is demonstrated by tax payments.

Analyzing the calculations data, represented in Table 12, let us point out that tax terms do not have a great impact on the enterprise survival rates during the first 3 or 5 years from their formation moment. Therefore statistically relevant effect is not obtained while evaluating nether tax rates nor tax administration indicators.

Let us note that economic development level is not also characterized by essential value to provide the enterprise survival rates, at the same time, high level of inflation reduces enterprise survival rates in 5-years period. On the other hand, tax administration indices are characterized by the statistically relevant effect of impact on the business growth. A stimulating effect is obtained for tax time, whereas the restraining effect is demonstrated by tax payments.

Table 12. Regression analysis of tax competition influence on enterprise survival rates in Eastern European and Baltic countries

\begin{tabular}{|l|c|l|l|c|l|l|}
\hline Variables & \multicolumn{3}{|c|}{ Survival 3 rate } & \multicolumn{3}{c|}{ Survival 5 rate } \\
\cline { 2 - 7 } & Model 1 & Model 2 & Model 3 & Model 4 & Model 5 & Model 6 \\
\hline Corporate tax & 0.04 & & & 0.03 & & \\
& $(0.06)$ & & & $(0.05)$ & & \\
\hline Indirect tax & 0.20 & & & -0.33 & & \\
& $(0.24)$ & & & $(-0.51)$ & & \\
\hline
\end{tabular}


Issue no. $27 / 2018$

\begin{tabular}{|c|c|c|c|c|c|c|}
\hline Employer tax & $\begin{array}{c}0.11 \\
(0.25)\end{array}$ & & & $\begin{array}{l}-0.32 \\
(-0.91)\end{array}$ & & \\
\hline Profit tax & & $\begin{array}{c}0.33 \\
(0.52)\end{array}$ & $\begin{array}{c}0.40 \\
(0.65)\end{array}$ & & $\begin{array}{c}0.46 \\
(0.78)\end{array}$ & $\begin{array}{c}0.54 \\
(1.01)\end{array}$ \\
\hline Labor tax & & $\begin{array}{c}-0.19 \\
(-0.48)\end{array}$ & & & $\begin{array}{c}0.27 \\
(0.88)\end{array}$ & \\
\hline Other taxes & & & $\begin{array}{c}0.00 \\
(0.01)\end{array}$ & & & $\begin{array}{c}0.29 \\
(0.81)\end{array}$ \\
\hline Tax time & & & $\begin{array}{c}0.00 \\
(0.12)\end{array}$ & & & \\
\hline Tax payments & & & $\begin{array}{l}-0.03 \\
(-0.59)\end{array}$ & & & $\begin{array}{l}-0.04 \\
(-0.88)\end{array}$ \\
\hline Inflation & $\begin{array}{l}0.03 \\
(0.05)\end{array}$ & $\begin{array}{c}0.33 \\
(1.16)\end{array}$ & $\begin{array}{c}0.35 \\
(1.19))\end{array}$ & $\begin{array}{l}-0.72 * \\
(0.42)\end{array}$ & $\begin{array}{c}-0.77 * * \\
(-2.04)\end{array}$ & $\begin{array}{c}-0.61 \\
(-1.46)\end{array}$ \\
\hline GDP growth & & $\begin{array}{c}0.04 \\
(0.22)\end{array}$ & $\begin{array}{c}0.03 \\
(0.15)\end{array}$ & & $\begin{array}{l}-0.13 \\
(-0.73)\end{array}$ & $\begin{array}{l}-0.20 \\
(-0.99)\end{array}$ \\
\hline $\begin{array}{l}\text { GDP per capita } \\
\text { growth }\end{array}$ & $\begin{array}{l}0.13 \\
(0.49)\end{array}$ & & & $\begin{array}{l}-0.13 \\
(-0.57)\end{array}$ & & \\
\hline _cons & $\begin{array}{c}45.67 * * \\
(1.99)\end{array}$ & $\begin{array}{c}56.78 * * * \\
(3.81)\end{array}$ & $\begin{array}{c}50.17 * * * \\
(7.41\end{array}$ & $\begin{array}{c}57.79 * * * \\
(3.21)\end{array}$ & $\begin{array}{c}37.36 * * * \\
(5.96)\end{array}$ & $\begin{array}{c}37.11 * * * \\
(5.84)\end{array}$ \\
\hline $\begin{array}{l}\text { Number } \\
\text { observations }\end{array}$ & 69 & 80 & 80 & 69 & 71 & 71 \\
\hline $\mathrm{F}$ & 0.73 & 2.33 & 2.55 & 8.89 & 9.41 & 9.41 \\
\hline Prob $>F$ & 0.9811 & 0.6750 & 0.8623 & 0.1136 & 0.0516 & 0.1517 \\
\hline
\end{tabular}


Issue no. $27 / 2018$

Note: $* * * p<0.01 ; * * p<0.05 ; * \mathrm{p}<0.1, \mathrm{z}$-statistics are in the brackets. Method: GLS random-effects regression

The last indicator, which describes the entrepreneurship development in the studied countries, is enterprise death rate. The obtained results of the tax and macroeconomic indicators impact on this index dynamics are demonstrated by the Table 13.

Statistically relevant results among the absolute and relative level of tax burden are obtained only for corporate tax. The increase of this index by on average $1 \%$ reduces the level of enterprise death rate by $0.35 \%$.

On the other side, indices of the tax administration have more stable effects. As a result, an increase of tax payments leads to the growth of enterprise death rate level by 0.05 $0.08 \%$. The increase of tax time by 1 hour causes reduction of the enterprise death rate on average by $0.01 \%$.

Table 13. Regression analysis of tax competition influence on enterprise death rate in Eastern European and Baltic countries

\begin{tabular}{|c|c|c|c|c|c|c|}
\hline Variables & Model 1 & Model 2 & Model 3 & Model 4 & Model 5 & Model 6 \\
\hline Corporate tax & $\begin{array}{l}-0.03 \\
(-0.11)\end{array}$ & $\begin{array}{l}-0.35^{* *} \\
(-2.25)\end{array}$ & $\begin{array}{c}0.02 \\
(0.10)\end{array}$ & & & \\
\hline Indirect tax & $\begin{array}{c}0.25 \\
(0.90)\end{array}$ & $\begin{array}{c}0.06 \\
(0.33)\end{array}$ & & & & \\
\hline Employer tax & $\begin{array}{c}0.11 \\
(0.72)\end{array}$ & $\begin{array}{c}-0.02 \\
(-0.21)\end{array}$ & $\begin{array}{c}-0.12 \\
(-0.99)\end{array}$ & & & \\
\hline Profit tax & & & & $\begin{array}{c}0.03 \\
(0.13)\end{array}$ & $\begin{array}{c}0.05 \\
(0.22)\end{array}$ & $\begin{array}{c}-0.09 \\
(-0.51)\end{array}$ \\
\hline Labor tax & & & & $\begin{array}{c}-0.06 \\
(-0.57)\end{array}$ & & \\
\hline Other taxes & & & & & -0.07 & -0.09 \\
\hline
\end{tabular}


Issue no. $27 / 2018$

\begin{tabular}{|c|c|c|c|c|c|c|}
\hline & & & & & $(-0.45)$ & $(-0.63)$ \\
\hline Tax time & & $\begin{array}{l}-0.01 * * \\
(-2.17)\end{array}$ & $\begin{array}{c}-0.01 \\
(-1.24)\end{array}$ & & & $\begin{array}{l}-0.00 \\
(-1.31)\end{array}$ \\
\hline Tax payments & & $\begin{array}{c}0.06^{* * *} \\
(3.66)\end{array}$ & $\begin{array}{c}0.08^{* * *} \\
(4.10)\end{array}$ & & & $\begin{array}{l}0.05^{* *} \\
(2.45)\end{array}$ \\
\hline Inflation & $\begin{array}{l}0.40^{* *} \\
(2.20)\end{array}$ & $\begin{array}{c}0.06 \\
(0.31)\end{array}$ & $\begin{array}{c}0.19 \\
(1.13)\end{array}$ & $\begin{array}{c}0.36^{* * *} \\
(2.95)\end{array}$ & $\begin{array}{c}0.35^{* * *} \\
(2.91)\end{array}$ & $\begin{array}{l}0.26^{* *} \\
(2.02)\end{array}$ \\
\hline GDP growth & $\begin{array}{c}-0.42 * * * \\
(-4.48)\end{array}$ & $\begin{array}{c}-0.29 * * * \\
(-3.05)\end{array}$ & & & & \\
\hline $\begin{array}{l}\text { GDP per capita } \\
\text { growth }\end{array}$ & & & $\begin{array}{c}-0.29 * * * \\
(-3.42)\end{array}$ & $\begin{array}{c}-0.35 * * * \\
(-4.17)\end{array}$ & $\begin{array}{c}-0.34 * * * \\
(-4.13)\end{array}$ & $\begin{array}{c}-0.29 * * * \\
(-3.52)\end{array}$ \\
\hline _cons & $\begin{array}{l}3.34 \\
(0.44)\end{array}$ & $\begin{array}{c}17.84 * * * \\
(3.67)\end{array}$ & $\begin{array}{c}15.04 * * * \\
(3.00)\end{array}$ & $\begin{array}{c}12.98^{* * *} \\
(3.31)\end{array}$ & $\begin{array}{c}11.01 * * * \\
(4.97)\end{array}$ & $\begin{array}{c}12.82 * * * \\
(6.24)\end{array}$ \\
\hline $\begin{array}{ll}\text { Number } & \text { of } \\
\text { observations } & \end{array}$ & 68 & 68 & 68 & 79 & 79 & 79 \\
\hline $\mathrm{F}$ & 24.07 & 42.73 & 41.97 & 19.24 & 19.91 & 26.87 \\
\hline Prob $>F$ & 0.0002 & 0.0000 & 0.0000 & 0.0007 & 0.0005 & 0.0002 \\
\hline
\end{tabular}

Note: ${ }^{* * *} \mathrm{p}<0.01 ;{ }^{*} \mathrm{p}<0.05 ;{ }^{*} \mathrm{p}<0.1, \mathrm{z}$-statistics are in the brackets. Method: GLS random-effects regression

In this context, one can note the great role of the economic development indices. The GDP growth by $1 \%$ provides a reduction of enterprise death rate by $0.29-0.42 \%$, and GDP per capita growth by $1 \%$ - reduction by $0.29-0.35 \%$ respectively. However, inflation is a destabilizing factor - the GDP deflator growth by $1 \%$ determines the increase of the enterprise death rate by $0.26-0.40 \%$. 
Issue no. $27 / 2018$

\section{Conclusions}

The analysis of the tax competition neoclassical models shows that nowadays the countries' tax policy, oriented to increase their tax competitiveness, is reasonable to be observed according to the following criteria:

- $\quad$ production factors, which make the object of the tax competition;

- the role of government in regulation and formation of the tax competition;

- $\quad$ the impact of tax competition on the territory welfare;

- the impact of territory size on the level of its tax competitiveness;

- change of the level and structure the tax burden under conditions of the tax competition;

- $\quad$ instruments of jurisdiction participation in the tax competition.

As it is defined above, the tax competition instruments are tax rates. It is empirically confirmed, that there are convergent tendencies of the main tax rates, which are paid by enterprises, for the Eastern European and Baltic countries. At the same time, the important factor to make decisions by taxpayers to choose countries for resources location, which form the taxation object, is quality of the tax administration in the country.

According to the results of the evaluation of tax competition instruments impact on the entrepreneurship development at different stages of the company's life cycle, the following results are obtained:

- the increase of absolute tax rates in general limits the entrepreneurial activity at the stage of enterprise creation and does not have a statistically relevant effect regarding the enterprise survival and their liquidation tendencies;

- the relative level of the tax burden is characterized by statistically relevant impact only on certain indicators of new businesses creation;

- indices of the tax administration have a statistically relevant effect on the entrepreneurial development at its different stages;

- macroeconomic conditions play a more significant role at the stages of company's creation and liquidation without any relevant effect regarding enterprise survival provision. 
Issue no. $27 / 2018$

\section{Acknowledgements}

The survey was supported by the Ministry of Education and Science of Ukraine and performed the results of the project "Modeling and forecasting of the socio-economicpolitical road map of reforms in Ukraine for the transition to a sustainable growth model" (registration number 0118U003569)

\section{References}

- BELÁS, J., DVORSKÝ, J., KUBÁLEK, J. and SMRČKA, L. (2018). Important factors of financial risk in the SME segment. Journal of International Studies, 11(1), 80-92.

- BetTendorf, L. and VRIJBURG, H. (2010) Asymmetric Corporate Tax Competition with Two Tax Instruments. [Online] Available from: https://www.researchgate.net/publication/228704411_Asymmetric_Corporate_Tax_Com petition_with_Two Tax Instruments [Accessed 10/05/2017].

- BlÖChliger, H. and PINERO-CAMPOS, J. (2011) Tax Competition Between SubCentral Governments. OECD Network on Fiscal Relations across Levels of Government Working Paper, 13, 45 p.

- BOBENIČ HINTOŠOVÁ, A., BRUOTHOVÁ, M., KUBÍKOVÁ, Z., and RUČINSKÝ R. (2018) Determinants of foreign direct investment inflows: A case of the Visegrad countries. Journal of International Studies, 11(2), pp. 222-235.

- BOIKO, A. and SAMUSEVYCH, I. (2017) The role of tax competition between the countries of the world and the features of determining the main tax competitors of Ukraine among the European countries. Financial Markets, Institutions and Risks, 1 (1), pp. 72-79.

- BOYARKO, I. M and SAMUSEVYCH, Y. V. (2011) Role of intangible assets in company's value creation. Actual Problems of Economics, 3(117), pp. 86-94.

- BUCOVETSKY, S. (1991) Asymmetric Tax Competition. Journal of Urban Economics, 30 (2), pp.167-181.

- CRIŞAN, C. M., DABIJA, D.-C. and DINU, V. (2015) Social Entrepreneurship in Romania: Significance and Models. Montenegrin Journal of Economics, 11 (2), pp. 6577. 
- DELGADO, F. J. (2013) Are Taxes Converging in Europe? Trends and Some Insights into the Effects of Economic Crisis. Journal of Global Economics, 1 (1), pp. 24-26.

- DUMA, F. (2014). Promoting the entreprenurship education in Europe. Online Journal Modelling the New Europe, (10), 67-79.

- ENSS, P. (2008) Tax Competition and Equalization with Assymetric Regions [Online] Available from: http://libra.msra.cn/Publication/5646995/tax-competition-andequalization-with-asymmetric-regions [Accessed 15/05/2017].

- FERNANDEZ, G. (2016) Strategic Tax Competition with a Mobile Population. Económica, 62, pp. 95-120.

- FIELD, T. (2003) Tax Competition in Europe and America. State Tax Notes, 98 (14), pp. 1211-1216.

- GoodspeEd, T. (1998) Tax Competition, Benefit Taxes and Fiscal Federalism. National Tax Journal, 51 (3), pp. 579-586.

- GORDON R. and WILSON G. (2002) Expenditure Competition. [Online] Michigan State University and University of Michigan. Available from: http://www.econ.ucsd.edu/ rogordon/zoning6.pdf [Accessed 15/08/2017].

- HAUfler, A. and WOOTON, I. (2007) Competition for Firms in an Oligopolistic Industry: Do firms or Countries Have to Pay? CESifo Working Paper, 1976, 31 p.

- HOYT, W. (1991) Property Taxation, Nash Equilibrium, and Market Power. Journal of Urban Economics, 34, pp. 123-131.

- HRYTSENKO L., and VYSOCHYNA A. (2012) Balanced Scorecard as an assessment tool for enterprise strategy. Actual Problems of Economy, 3 (129), pp. 161-167.

- HUIZINDA, H. and NIELSEN, S. (1997) Capital income and profit taxation with foreign ownership of firms. Journal of International Economics, 42, pp. 149-165.

- JANEBA, E. (2001) Attracting FDI in a Politically Risky World. National Bureau of Economic Research Inc. Working Paper, 8400, 36 p.

- KEMP, M. (1961) Foreign Investment and National Advantage. The Economic Record, 28, pp. 56-62. 
- KHAN, M. Y. H. (2018) The Effectiveness of Entrepreneurial Activities for Economic Development: A Route to Innovation and Job Generation. Socio Economic Challenges, 2 (2), pp. 32-40.

- KIND, H. MIDELFART-KNARVIK, K. and SCHJELDERUP, G. (2000) Competing for Capital in a Lumpy World. Journal of Public Economics, 78(3), pp. 253-274.

- KLEINSCHMIDT, H. (2017) Labor Movements, Mainly in Eastern Europe. SocioEconomic Challenges, 1 (3), pp. 45-50.

- KOZUBÍKOVÁ, L., BELÁS, J., BILAN, Y. and BARTOŠ, P. (2015) Personal characteristics of entrepreneurs in the context of perception and management of business risk in the SME segment. Economics and Sociology, Vol. 8, No 1, pp. 41-54.

- LAZÁNYI, K. (2015). What makes a start-up successful?-Small business ventures in focus. On-line Journal Modelling the New Europe, (16), 68-79

- LAZÁNYI, K. (2014). Entrepreneurial skills and competencies of students at Óbuda University. On-line Journal Modelling the New Europe, (10), 17-28.

- LEONOV, S. V., VASYLIEVA, T. A. and TSYGANYUK, D. L. (2012) Formalization of functional limitations in functioning of co-investment funds basing on comparative analysis of financial markets within FM CEEC. Actual Problems of Economics, 134(8), pp. $75-85$.

- LYEONOV, S. V., VASYlieVA, T. A. and LYUlyOV, O. V. (2018) Macroeconomic stability evaluation in countries of lower-middle income economies. Naukovyi Visnyk Natsionalnoho Hirnychoho Universytetu, (1), pp. 138-146.

- MACDOUGALL, G. (1960) The benefits and Costs of Private Investments from Abroad: A Theoretical Approach. Economic Record, 36, pp. 13-35.

- MUKHERJEE, S. (2018) Cross Country Tax Competition and its Impact on Multinational Corporations - a Theoretical Re-examination. Financial Markets, Institutions and Risks, 2 (1), pp. 97-104.

- OATES, W. and SCHWAB, R. (1998) Economic Competition Among Jurisdictions: Efficiency Enhancing or Distortion Inducing? Journal of Public Economics, 35, pp. 333354. 
- POMIANEK, I. (2018) Historical and Contemporary Approaches to Entrepreneurship. Review of Polish Literature. Business Ethics and Leadership, 2 (2), pp. 74-83.

- PRINCE, T. (2017) Behavioral Finance and the Business Cycle. Business Ethics and Leadership, 1 (4), pp. 28-48.

- RAZIN, A. and SADKA, E. (1989) International Tax Competition and Gains from Tax Harmonization. National Bureau of Economic Research Working Paper, 3152, 25 p.

- SAMUSEVYCH, Y. (2014) Defining the role of the tax administration in shaping the country's tax competition. Mechanism of regulation of the economy, 4, pp. 174-180.

- TEATHER, R. (2005) The Benefits of Tax Competition. The Institute of Economic Affairs, $167 \mathrm{p}$.

- TIEBOUT, C. A (1956) Pure Theory of Local Expenditures. Journal of political Economy, 64 (5), pp. 416-424.

- VASIlyeVA, T., LYEONOV, S., ADAMIČKOVÁ, I. and BAGMET, K. (2018a) Institutional quality of social sector: The essence and measurements. Economics and Sociology, 11(2), pp. 248-262.

- VASYliEVA, T. A. and KASYANENKO, V. O. (2013) Integral assessment of innovation potential of Ukraine's national economy: A scientific methodical approach and practical calculations. Actual Problems of Economics, 144(6), pp. 50-59.

- VASYliEVA, T., LYEONOV, S., LYULYOV, O. and KYRYCHENKO, K. (2018b) Macroeconomic stability and its impact on the economic growth of the country. Montenegrin Journal of Economics, 14(1), pp. 159-170.

- WILDASIN, D. (1988) Nash Equilibria in Models of Fiscal Competition. Journal of Public Economics, 35 (2), pp. 229-240.

- WILSON, J. (1999) Theories of Tax Competition. National Tax Journal, 52, pp. 269-304.

- ZODROW, G. and MIESZKOWSKI, P. (1986) Pigou, Tiebout, property taxation and the underprovision of local public goods. Journal of Urban Economic, 19, pp. 356-370. 